\title{
Peningkatan Hasil Belajar PKn Melalui Model Word Square Kelas 3 MIS NU 2 Pontianak
}

\author{
Fathurrosi \\ IAIN Pontianak \\ RendraRossi@gmail.com \\ Nikmatur Rohmah \\ IAIN Pontianak \\ rohmayarohma95@gmail.com
}

\begin{abstract}
PKN Subject is on one of lesson implemented on SD, SMP and SMA to apply student characters and to form the student to understand and love home land also understand global life. The research background of the low student achievement on study still using lecture method, giving assignments, answer and guestion on PKN subject. The purposes of this research: 1.how student achievement on PKN subject before using word sguare model. 2. How student achievement on PKN subject after using calassroom action rescarch with quantitative approach. The sample is the students of class III MIS NU 2 Pontianak.in order to get the data, researcher using observation shett, measurement technique and documentation study. The result concluded: 1.the student achievement before using word square model the average is 53 ( good category) with KKM > 70 as 5 or $25 \%$ and students with KKM $<70$ as 15 students or $75 \%$. 2. The student achievement after using word square on cycle 1 is 68,5 ( Better category) with KKM 55\%. On the other hands, cycle 11 is 82,5 (Great category) with KKM $90 \%$.
\end{abstract}

\section{Keywords: Word Square Model; Students Achievement}

\begin{abstract}
Abstrak
Mata pelajaran PKn salah satu pelajaran yang diterapkan mulai dari SD, SMP dan SMA dengan membekali karakter dan membentuk peserta didik cinta tanah air dan paham dalam kehidupan yang serba global. Rumusan penelitian ini; 1) Bagaimana hasil belajar siswa pada mata pelajaran pendidikan kewarganegaraan sebelum menggunakan model pembelajaran word square kelas 3 MIS NU 2 Pontianak. 2) Bagaimana hasil belajar siswa
\end{abstract}


pada mata pelajaran pendidikan kewarganegaraan setelah menggunakan model pembelajaran word square kelas 3 MIS NU 2 Pontianak. Metode dan jenis penelitian ini menggunakan jenis penelitian tindakan kelas dengan pendekatan kuantitatif. Subjek penelitian ini adalah siswa kelas III MIS NU 2 Pontianak. Untuk mendapatkan data peneliti menggunakan lembar observasi, teknik pengukuran dan studi dokumentasi. Hasil dari penelitian ini yaitu: 1) Hasil belajar siswa pada Mata Pelajaran PKn sebelum menggunakan model pembelajaran Word Square diperoleh nilai rata-rata sebesar 53 (kategori cukup) dengan siswa yang tuntas mencapai nilai KKM $\geq 70$ sebanyak 5 atau $25 \%$ dan siswa yang tidak tuntas dengan nilai KKM $\leq$ 70 sebanyak 15 siswa atau 75\%. 2) Hasil belajar siswa pada Mata Pelajaran PKn setelah menggunakan model pembelajaran Word Square pada siklus I sebesar 68,5 (kategori baik) dan siswa yang mencapai KKM sebesar 55\%. Sedangkan pada siklus II sebesar 82,5 (kategori sangat baik) dan siswa yang mencapai KKM sebesar 90.

Kata Kunci: Model Pembelajaran Word Square; Hasil Belajar

\section{PENDAHULUAN}

Pendidikan merupaka usaha sadar dan terencana untuk mewujudkan suasana belajar dan proses pembelajaran agar peserta didik secara aktif mengembangkan potensi dirinya untuk memiliki kekuatan spritual keagamaan, pengenalan diri, keperibadian, kecerdasan, akhlak mulia, serta keterampilan yang diperlukan dirinya, masyarakat, bangsa dan negara.

Menurut Haitami Salim dan Erwin Mahrus (2010) Pendidikan adalah pengembangan pribadi dalam semua aspeknya, yang mencakup pendidikan oleh diri sendiri, pendidikan oleh lingkungan, dan pendidikan oleh orang lain (guru) yang mencakup aspek jasmani, rohani, dan hati. Pendidikan berusaha mengembangkan seluruh aspek kepribadian dan kemampuan manusia, baik aspek kognitif maupun psikomotorik. ${ }^{1}$ Dalam proses

\footnotetext{
${ }^{1}$ Haitami Salim dan Erwin Mahrus, Filsafat Pendidikan Islam, (Pontianak: STAIN Pontianak Press, 2010), 10.
} 
pendidikan di Sekolah Dasar (SD) terdapat banyak mata pelajaran yang akan diajarkan oleh guru salah satunya adalah mata pelajaran Pendidikan Kewarganegaraan (PKn), dimana mata pelajaran pendidikan kewarganegaraan ini bertujuan untuk mengembangkan siswa menjadi manusia yang memiliki rasa kebangsaan dan cinta tanah air, melalui proses menerima dan menjalankan ajaran agama yang dianutnya, memiliki perilaku jujur, disiplin, tanggung jawab, santun, peduli, dan percaya diri dalam berinteraksi dengan keluarga, teman, dan guru, dan menerapkan pengetahuan faktual dan konseptual tentang kewarganegaraan.

Undang-Undang Dasar Republik Indonesia Nomor 20 Tahun 2003 tentang Sistem Pendidikan Nasional pada pasal 1 disebutkan bahwa pendidikan adalah usaha sadar dan terencana untuk mewujudkan suasana belajar dan proses pembelajaran siswa secara aktif mengembangkan potensi dirinya untuk memiliki kekuatan spiritual, keagamaan, pengendalian diri, kepribadian, kecerdasan, akhlak mulia, serta keterampilan yang diperlukan dirinya, masyarakat, bangsa dan negara. ${ }^{2}$ Sebagaimana dalam UndangUndang Dasar Republik Indonesia Nomor 20 Tahun 2003 Sistem Pendidikan Nasional Pasal 37 menyebutkan bahwa pendidikan kewarganegaraan untuk membentuk siswa menjadi manusia yang memiliki rasa kebanggaan dan cinta tanah air.

Mata pelajaran pendidikan kewarganegaraan (PKn) merupakan mata pelajaran yang diajarkan dalam lembaga pendidikan, mengingat pelajaran PKn ini bertujuan untuk membentuk karakter dan watak yang baik bagi peserta didik dalam kehidupan yang kompleks serta memiliki tanggung jawab untuk bangsa dan negara. Peneliti berkeyakinan bangsa yang berkembang dan maju harus dimulai dari pendidikan sejak dini, maka tidak heran semua negara selalu mengutamankan dunia pendidikn. Model pembelajaran word square ini sangat cocok diterapkan di kelas, sebab

\footnotetext{
${ }^{2}$ Hasbullah, Dasar-Dasar Ilmu Pendidikan, (Jakarta: Raja Grafindo Persada, 2011), 4.
} 
model dalam pembelajaran tersebut lebih menekankan pada aktivitas, disiplin, berfikir kritis dan aktif, serta melatih siswa untuk lebih teliti. Berdasarkan hasil studi dokumentasiyang dilakukan oleh peneliti terhadap perolehan hasil belajar siswa di kelas III MIS NU 2 Pontianak, diketahui bahwa hasil belajar siswa pada mata pelajaran pendidikan kewarganegaraan masih tergolong rendah karena masih banyak siswa yang mendapatkan nilai dibawah $\mathrm{KKM} \leq 70$, dari jumlah 25 siswa, pada nilai evaluasi akhir semester menunjukkan sebanyak 9 siswa yang mendapatkan nilai diatas $K K M \geq 70$, sedangkan 16 siswa lainnya mendapatkan nilai dibawah $K K M \leq$ 70. Berdasarkan data di atas, maka peneliti menerapkan model pembelajaran word square untuk meningkatkan pemahaman dan hasil belajar siswa khususnya dalam pelajaran PKn.

Hasil belajar yang diperoleh menunjukkan bahwa, dalam pelaksanaan proses belajar mengajar di sekolah, ada tiga sebab hasil belajar rendah yaitu dari faktor siswa yang kurang memperhatikan materi pelajaran yang disampaikan oleh guru, siswa hanya memperhatikan dan mendengarkan materi, sehingga proses belajar mengajar menjadi kurang menarik. Adapun dari faktor guru yang masih dominan menerapkan metode ceramah dan mencatat pelajaran, hal ini tentu menghambat ketercapain tujuan PKn itu sendiri, dan juga faktor lingkungan yang kurang mendukung seperti kurangnya metode dan sarana untuk mengajar. Maka diperlukan proses belajar mengajar yang dilakukan guru harus menarik dengan menggunakan model pembelajaran yang sesuai untuk tingkat perkembangan anak sekolah dasar khususnya anak kelas III MIS NU 2 Pontianak.

Hamiyah dan Jauhar (2014) menyatakan model pembelajaran merupakan teknik atau cara penyajian yang digunakan guru dalam proses pembelajaran agar tercapai tujuan pembelajaran itu sendiri. ${ }^{3}$ Sedangkan Trianto (2010) mengartikan model pembelajaran adalah kerangka

\footnotetext{
${ }^{3}$ Hamiyah dan Jauhar, Strategi Belajar Mengajar Di Kelas, (Jakarta: Prestasi, 2014), 57.
} 
konseptual yang melukiskan prosedur yang sistematis dalam mengorganisasikan pengalaman belajar untuk mencapai tujuan belajar tertentu, dan berfungsi sebagai pedoman bagi para perancang pembelajaran dan para pengajar dalam merencanakan aktivitas belajar mengajar.

Oleh karena itu, melihat permasalahan di atas peneliti memilih penggunaan model pembelajaran Word Square sebagai solusi yang tepat karena model pembelajaran ini berorientasi kepada keaktifan siswa dalam pembelajaran sehingga diharapkan dapat meningkatkan hasil belajar siswa terutama dalam mata pelajaran Pendidikan Kewarganegaraan.

\section{MODEL PEMBELAJARAN WORD SQUARE}

Di dalam Word square siswa diberi pengarahan oleh peneliti untuk membaca dan memahami materi yang akan disampaikannya. Kemudian peneliti membagi siswa dalam kelompok kecil yang bertujuan untuk menjelaskan materi dalam bentuk media word square dengan bentuk menampilkan kotak yang sudah diisi dengan huruf-huruf yang didalamnya terdapat kata-kata secara berhubungan dengan materi yang dijelaskan. Siswa diarahkan supaya bisa menemukan kata yang berhubungan langsung dengan materi, melalui bimbingan peneliti dan guru. Siswa akan paham dan lebih mudah serta bisa menyampaikan apa maksud dari kata itu sendiri sesuai dengan pemahaman dan penjelasan peneliti.

Menurut Suyadi model adalah gambaran kecil atau miniatur dari sebuah konsep besar. Model pembelajaran adalah gambaran kecil dari konsep pembelajaran secara keseluruhan. ${ }^{4}$ Termasuk dalam hal ini adalah tujuan, sintaksis, lingkungan, dan sistem pengelolaan. Atas dasar ini, model pembelajaran mempunyai makna lebih luas dari istilah lain, seperti pendekatan, strategi dan metode. Dengan demikian, model pembelajaran adalah suatu perencanaan atau pola yang digunakan sebagai pedoman dalam

\footnotetext{
${ }^{4}$ Suyadi, Strategi Pembelajaran Pendidikan Karakter, (Bandung: Remaja Rosdakarya, 2013), 14.
} 
merencanakan pembelajaran. Pembelajaran yang dimaksud disini termasuk penggunaan media pembelajaran secara umum, seperti buku-buku, film, komputer, kurikulum, dan lain-lain. ${ }^{5}$ Setiap model pembelajaran mengarah kepada desain pembelajaran untuk membantu peserta didik sedemikian rupa sehingga tujuan pembelajaran tercapai secara efektif dan efisien.

Dari beberapa teori di atas dapat disimpulkan bahwa model pembelajaran yaitu rancangan kerangka konseptual dan operasional dalam melaksanakan kegiatan pembelajaran. Model pembelajaran merupakan bentuk pembelajaran yang tergambar dari awal pembelajaran sampai akhir pembelajaran yang disajikan secara khas oleh guru di kelas. Dalam model pembelajaran terdapat strategi pencapaian kompetensi siswa dengan pendekatan, metode, dan teknik pembelajaran.

\section{Langkah-Langkah Model Word Square}

Menurut Imas Kurniasih dan Berlin Sani, (2015) langkah model pembelajaran word square adalah:

a. Guru menyampaikan materi sesuai dengan tujuan pelajaran materi tersebut.

b. Guru membagikan lembaran kegiatan sesuai arahan yang ada.

c. Siswa menjawab soal kemudian mengatur huruf dalam kotak sesuai jawab vertikal, horizontal maupun diagonal.

d. Berikan poin setiap jawaban dalam kotak. ${ }^{6}$

Dari pendapat diatas dapat disimpulkan bahwa langkah-langkah model pembelajaran word square yang diterapkan dalam penelitian ini adalah sebagai berikut:

a. Guru menyampaikan materi sesuai dengan tujuan pelajaran materi tersebut. Pada bagian ini peneliti dan guru menyampaikan materi yang

\footnotetext{
${ }^{5}$ Ibit, 14.

${ }^{6}$ Imas Kurniasih dan Berlin Sani, Ragam Pengembangan Model Pembelajaran Untuk Meningkatkan Profesional Guru, (Yogyakarta: Kata Pena, 2015), 98.
} 
sudah dirumuskan dalam pembelajaran untuk dapat dipahami secara mudah dan memfokuskan pada satu tema atau sub tema.

b. Kemudian siswa mendengarkan penjelasan materi yang disampaikan oleh peneliti serta guru langsung memperhatikan kegiatan yang dilakukan terkait materi yang diajarkan.

c. Kemudian peneliti dan guru memberikan kesempatan untuk melakukan tanya jawab kepada siswa terkait materi yang telah disampaikan.

d. Peneliti dan guru mulai fokus pada kegiatan siswa yang dilakukan dengan membagikan lembar kegiatan berupa susunan huruf abjad yang mengandung kata yang terdapat dalam materi tersebut.

e. Peneliti menempelkan media karton ke papan tulis yang berkaitan dengan model word square.

f. Setelah media di tempel, guru terlebih dahulu menyampaikan cara kerja dalam menjawab soal dalam kotak word square.

g. Siswa menjawab soal kemudian mengarsir huruf dalam kotak sesuai jawaban vertikal, horizontal, maupun diagonal dengan cara mengarsir jawaban yang benar sesuai dengan soal yang dibuat.

h. Siswa maju kedepan menuliskan jawaban yang mereka temukan dalam kotak word square.

i. Guru membahas hasil jawaban siswa dan memberikan penghargaan kepada siswa yang dapat menjawab soal dengan benar.

j. Guru memberikan poin pada setiap jawaban yang benar dalam kotak word square

Berdasarkan langkah-langkah teori pembelajaran word square di atas, peneliti memandang sangat perlu untuk melakukan penelitian tersebut dengan menerapkannya model pembelajaran word square di sekolah MIS NU 2 Kelas III Pontianak yang dapat memberikan pengalaman baru dalam proses belajar serta meningkatkan hasil belajar pada mata pelajaran PKn. 


\section{Kelebihan Dan Kekurangan Model Word Square}

Menurut Imas Kurniasih dan Berlin Sani ${ }^{7}$ (2015) kelebihan model pembelajaran word square sebagai berikut:

a. Proses pembelajaran dengan model word square mendorong pemahaman siswa terhadap materi pelajaran.

b. Siswa akan terlatih untuk disiplin.

c. Sebagai latihan untuk bersikap teliti dan kritis.

d. Merangsang siswa untuk berfikir aktif.

Sedangkan kekurangan dari model pembelajaran word square dalam pembelajaran sebagai berikut:

a. Dengan materi yang telah dipersiapkan akhirnya dapat menumbuhkan keaktifan siswa.

b. Siswa tinggal menerima bahan mentah.

c. Siswa tidak dapat mengembangkan materi yang ada dengan kemampuan atau potensi yang dimilikinya.

Untuk mengatasi kekurangan yang ada pada model word square, maka dapat dilakukan tanya jawab terlebih dahulu untuk mengetahui kemampuan siswa dengan cara mengaitkan materi pelajaran yang akan dibahas dengan kehidupan sehari-hari.

\section{Pembelajaran Pendidikan Kewarganegaraan (PKN)}

Menurut Noorhafizah dan Robiah, (2016) Pendidikan Kewarganegaraan adalah mata pelajaran yang digunakan sebagai wahana untuk mengembangkan dan melestarikan nilai luhur dan moral yang berakar pada budaya bangsa Indonesia. ${ }^{8}$ Nilai luhur dan moral ini dapat diwujudkan dalam bentuk perilaku kehidupan siswa sehari-hari, baik sebagai individu maupun anggota masyarakat, yang memfokuskan siswa agar dapat mengembangkan diri dalam pembentukan karakter yang mampu memahami

${ }^{7}$ Ibid, 98.

${ }^{8}$ Noorhafizah dan Robiah. (Jurnal Pradigma. Volume 1, 20016), 1. 
dan melaksanakan nilai-nilai luhur dan moral bangsa sehingga menjadi siswa yang terampil dan berkarakter sesuai dengan pengamalan pancasila dan UUD 1945.

\section{Tujuan Pembelajaran Pendidikan Kewarganegaraan}

Menurut Achmad Ubaedillah dan Abdul Rozak (2005) Pendidikan Kewarganegaraan bertujuan membangun karakter bangsa Indonesia antara lain:

a. Membentuk kecakapan partisipasi warga negara yang bermutu dan bertanggung jawab dalam kehidupan bangsa dan bernegara.

b. Menjadikan warga Negara Indonesia yang cerdas, aktif, dan demokratis, namun tetap memiliki komitmen menjaga persatuan dan integritas bangsa.

c. Mengembangkan kultur demokrasi yang berkeadaban, yaitu kebebasan, persamaan, toleransi dan tanggung jawab. ${ }^{9}$

Tujuan pembelajaran Pendidikan Kewarganegaraan di sekolah dasar (SD) dalam BSNP (2011) bertujuan agar siswa memiliki kemampuan sebagai berikut:

a. Berfikir secara kritis, rasional, dan kreatif dalam menanggapi isu kewarganegaraan.

b. Berpartisipasi secara aktif dan tanggung jawab, bertindak secara cerdas dalam kegiatan bermasyarakat, berbangsa, dan bernegara, serta anti korupsi.

c. Berkembang secara positif dan demokratis untuk membentuk diri berdasarkan karakter-karakter masyarakat Indonesia agar dapat hidup bersama dengan bangsa-bangsa lainnya.

\footnotetext{
${ }^{9}$ Achmad Ubaedillah dan Abdul Rozak, Pendidikan Kewarganegaraan, Demokrasi, Hak Asisi Manusia, Dan Masyarakat Madani, (Jakarta: Prenada Media, 2005), 13.
} 
d. Berinteraksi dengan bangsa-bangsa lain dalam percaturan dunia serta langsung atau tidak langsung dengan memanfaatkan teknologi informasi dan komunikasi. ${ }^{10}$

\section{Ruang Lingkup Mata Pelajaran Pendidikan Kewarganegaraan}

Ruang lingkup dalam BSNP (2011) dijelaskan bahwa Kurikulum PKn Pendidikan Dasar dan Pendidikan Menengah disusun dengan ruang lingkup sebagai berikut:

a. Pancasila, sebagai dasar negara, ideologi nasional, dan pandangan hidup bangsa. (Menghayati dan bersikap penuh tanggung jawab sesuai nilainilai Pancasila dalam kehidupan sehari-hari, Menganalisis dan menerapkan keputusan bersama berdasarkan nilai-nilai Pancasila dalam kehidupan sehari-hari. Mensyukuri dan mendukung perwujudan Pancasila sebagai dasar Negara, Menganalisis dan mendemonstrasikan langkah-langkah untuk mewujudkan Pancasila sebagai Dasar Negara. Menghayati dan menghargai nilai-nilai yang melekat dalam pelanggaran hak dan pengingkaran kewajiban warga negara sesuai dengan Pancasila dalam kehidupan berbangsa dan bernegara).

b. Undang-Undang Dasar Negara Republik Indonesia Tahun 1945 sebagai hukum dasar tertulis yang menjadi landasan konstitusional kehidupan bermasyarakat, berbangsa, dan bernegara. (Menghargai dan melaksanakan kewajiban, hak, dan tanggung jawab sebagai warga Negara; Merasionalkan dan menyajikan pelaksanaan kewajiban, hak, dan tanggung jawab sebagai warga negara terhadap kehidupan sehari-hari. Mensyukuri dan mendukung nilai-nilai yang menunjukkan perilaku orang beriman dalam praksis pelindungan dan penegakan hukum dalam masyarakat).

\footnotetext{
10 BSNP, Kurikulum Tingkat Satuan Pendidikan SD/MI. (Jakarta: Departemen Pendidikan Nasional, 2011), 271.
} 
c. Negara Kesatuan Republik Indonesia, sebagai kesepakatan final bentuk negara Republik Indonesia. (Meyakini dan mendukung dengan rasa tanggung jawab persatuan dan kesatuan sebagai anugerah Tuhan yang Maha Esa. Menghargai dan mendukung konsep bela Negara dalam konteks Negara Kesatuan Republik Indonesia. Mengembangkan dan mempertahankan nilai-nilai persatuan dan kesatuan bangsa dengan jujur di masa yang akan datang sebagai upaya dalam menjaga dan mempertahankan Negara Kesatuan Republik Indonesia.

\section{Hakikat Hasil Belajar}

Menurut Nana Sudjana, (2005), hasil belajar dibagi menjadi 3 ranah yaitu, ranah kognitif, ranah afektif, dan ranah psikomotorik. ${ }^{11}$ Namun dalam penelitian ini, peneliti hanya menguraikan aspek kognitif yang memang lebih menfokuskan pada aspek tersebut. Adapun ranah Kognitif dapat dilihat pada tipe-tipe berikut;

1) Tipe hasil belajar pengetahuan

Tipe ini termasuk ranah kognitif yang paling rendah karena hanya sebatas pengetahuan dasar, misalnya siswa hanya hafalan dalam mengingat suatu rumus tertentu.

2) Tipe hasil belajar pemahaman

Pada tipe ini siswa telah mampu untuk menjelaskan sesuatu dengan kalimat atau bahasanya sendiri.

3) Tipe hasil belajar aplikasi

Penggunaan ide atau teori baru yang lebih dikembangkan namun tetap mengacu pada teori dasar.

4) Tipe hasil belajar analisis

Analisis merupakan bagaimana memahami cara bekerja sesuatu dan memahami suatu proses. Analisis merupakan tipe hasil belajar yang

\footnotetext{
${ }^{11}$ Nana Sudjana, Penelitian Hasil Proses Belajar, 23-30.
} 
kompleks yang memanfaatkan unsur tipe hasil belajar sebelumnya yaitu pengetahuan, pemahaman, aplikasi.

5) Tipe hasil belajar sintesis

Berpikir sintesis adalah berpikir divergen. Berpikir divergen adalah untuk menjadikan orang lebih kreatif. Arti kreatif disini yaitu menemukan atau menciptakan sesuatu hal yang baru.

6) Tipe hasil belajar evaluasi

Evaluasi merupakan pemberian yang diberikan untuk menilai sesuatu sesuai dengan tujuan yang hendak dicapai.

\section{METODE DAN JENIS PENELITIAN}

Metode yang digunakan dalam penelitian ini adalah metode kuantitatif deskriptif. Sedangkan Jenis dalam penelitian ini adalah menggunakan penelitian tindakan kelas (classroom action research) dengan menekankan pada proses dan hasil akhir belajar siswa. Menurut Wina Sanjaya (2009). Penelitian tindakan kelas (PTK) dapat diartikan sebagai proses perangkaian masalah pembelajaran di dalam kelas melalui refleksi dari dalam supaya untuk memecahkan masalah tersebut dengan cara melakukan berbagai tindakan yang terencana dalam situasi nyata serta menganalisis setiap pengaruh dari perlakuan tersebut. Adapun tahapan-tahapan penelitian tindakan kelas yang dilakukan oleh peneliti meliputi: 1), tahapan perencanaan. Dalam tahapan ini peneliti berkolaborasi dengan guru kelas untuk menyusun semua prangkat pembelajaran yang berhubungan dengan proses belajar mengajar. 2), tahapan pelaksanaan, pada tahapan ini peneliti dan guru mulai menerapkan model pembelajaran word square di kelas. 3) Tahapan pengamatan ini juga meliputi aktivitas yang dipantau secara langsung oleh guru dan peneliti dalam menentukan keberhasilan pada hasil belajar siswa. 4) pada tahapan refleksi ini peneliti dan guru mulai melakukan perbandingan mengenai proses yang telah berlangsung selama model pembelajaran word square diterapkan di kelas tersebut. Keempat 
tahapan di atas merupakan langkah untuk menentukan siklus dalam penelitian yang meliputi dari tigas siklus. Sedangkan instrumen yang digunakan dalam penelitian ini adalah lembar observasi dan lembar soal. Lembar observasi ini bertujuan untuk mengumpulkan data dalam proses pembelajaran yang terdiri dari lembar observasi guru dan observasi siswa. Sementara tes yang digunakan dalam penelitian ini adalah tes tertulis yang berupa tes pilihan ganda.

\section{TEMUAN PENELITIAN}

\section{Proses Hasil Belajar Siswa Pada Mata Pelajaran PKn Dengan}

\section{Menggunakan Model Pembelajaran Word Square}

Proses hasil belajar siswa pada Mata Pelajaran PKn dengan menggunakan model pembelajaran word square di kelas III MIS NU 2 Pontianak. Berdasarkan hasil lembar observasi yang dilakukan oleh observer yaitu ibu Siti Aminah, S, Pd.I dapat diketahui bahwa pada proses pembelajaran yang dilakukan peneliti pada siklus I dan siklus II telah dilakukan sesuai dengan langkah-langkah model pembelajaran word square. Hasil belajar siswa dapat dikatakan baik ataupun berhasil jika pendidik atau guru mampu mengunakan model-model pembelajaran yang memberikan pengalaman baru bagi siswa di kelas.

Purwanto dan Thobroni (2015) mengatakan bahwa berhasil atau tidaknya hasil belajar dipengaruhi oleh beberapa faktor yang timbul dari dirinya sendiri atau yang muncul dari lingkungan sosial. Misalnya 1) faktor keluarga, 2) faktor guru dan cara mengajarnya ${ }^{12}$. Pada saat guru mengajar di kelas kemampuan dan cara seorang guru dalam mengajar merupakan foktor penting keberhasilan siswa termasuk dalam ketepatan model yang digunakan. Jika berangkat dari teori di atas, maka guru harus melakukan model pembelajaran yang bisa meningkatkan hasil dan semangat belajar

\footnotetext{
${ }^{12}$ Purwanto dan Thobroni, Belajar dan Pembelajaran, (Yogyakarta; Ar-Ruzz Media, 2015),
} 
siswa termasuk model pembelajaran word square yang sangat cocok dilakukan di kelas dengan pembelajaran yang memadukan kemampuan menjawab pertanyaan dengan kejelian mencocokkan jawaban pada kotakkotak jawaban.

\section{Hasil Belajar Siswa Pada Mata Pelajaran Pkn Setelah Menggunakan Model Pembelajaran Word Square}

Pada bagian ini, sebelum instrumen digunakan oleh guru saat mengajar, peneliti mengecek validitas instrumennya terlebih dahulu apakah instrumen tersebut valid atau tidak, maka guru dapat menggunakan instrumen tersebut sebagai alat penelitian. Instrumen yang digunakan pada siklus I dan siklus II sama. Dalam penelitian ini digunakan test sebelum menggunakan model pembelajaran word square dan setelah menggunakan model pembelajaran word square pada satu kelas.

Penerapan model word square memiliki dampak perubahan pada nilai hasil pengetahuan siswa dan juga prosesnya selama pembelajaran berlalu. Beberapa dampak yang nampak seperti antusiasnya siswa dalam mengikuti pelajaran, siswa dapat mendapatkan informasi dari teman sebangkunya, siswa dapat saling bekerjasama dan bertukar pikiran, dan siswa dapat menjawab soal pertanyaan word square dengan cepat dan tepat.

Adapun hasil belajar siswa setelah diterapkannya model word square pada siklus I sebesar 68,5 (kategori baik) dan siswa yang mencapai KKM $\geq$ 70 sebesar 55\%. Sedangkan pada siklus II sebesar 82,5 (kategori sangat baik) dan siswa yang mencapai KKM $\geq$ sebesar 90\%. Jadi jika di interprestasikan ke tabel distribusi frekuensi maka nilai rata-rata kelas setelah menggunakan model pembelajaran Word Square termasuk pada kategori sangat baik yaitu antara 80-100\%. 
Tabel.1

Data Persentase Ketuntasan Hasil Belajar Siswa dari Siklus I ke Siklus II Kelas III MIS NU 2 Pontianak

\begin{tabular}{|l|c|c|c|}
\hline \multicolumn{1}{|c|}{ Data yang diperoleh } & Siklus I & Siklus II & Kenaikan \\
\hline Jumlah Siswa & 20 & 20 & - \\
\hline Hasil Belajar Klasikal & $55 \%$ & $90 \%$ & $35 \%$ \\
\hline
\end{tabular}

Sumber: Dokumentasi Peneliti 2019

Hasil belajar siswa dari siklus I ke siklus II mengalami perubahan yang signifikan. Perubahan tersebut tentu saja dipengaruhi oleh banyak faktor, terutama faktor internal yang berasal dari diri siswa sendiri, yang awalnya bermalas-malasan untuk belajar ketika bersemangat dan rajin untuk belajar maka akan mendapatkan hasil yang lebih meningkat dari sebelumnya. Dapat disimpulkan bahwa penggunaan model pembelajaran word square dinyatakan berhasil karena dapat meningkatkan hasil belajar siswa pada mata pelajaran PKn di kelas III MIS NU 2 Pontianak, adapun kelebihan pada model pembelajaran word square ini adalah: 1) Siswa akan terlatih untuk disiplin. 2) Sebagai latihan untuk bersikap teliti dan kritis. 3) Merangsang siswa untuk berfikir aktif.

Menurut Nasution, (dalam Kunandar, 2013) bahwa hasil belajar adalah suatu perubahan pada individu yang belajar, yang tidak hanya mengenai pengetahuan, tetapi juga bentuk-bentuk kecakapan dan penghayatan dalam diri pribadi individu yang belajar. Dapat dihubungkan bahwa tindakan yang dilakukan oleh peneliti sudah berhasil dalam pelaksanaan penelitian ini. Hal itu dapat dilihat data yang sudah dipaparkan oleh peneliti yang mana setiap siklus selalu berada pada peningkatan yang signiikan.

Menurut Nana sudjana (2005) Pengertian hasil belajar adalah kemampuan-kemampuan yang dimiliki siswa setelah ia menerima 
pengalaman belajarnya. ${ }^{13}$ Sedangkan Suprijono hasil belajar adalah polapola perbuatan, nilai-nilai, pengertian-pengertian, sikap-sikap, apresiasi dan keterampilan. ${ }^{14}$ Dengan demikian, dari beberapa pendapat para ahli diatas dapat disimpulkan bahwa hasil belajar adalah perubahan tingkah laku yang terjadi secara keseluruhan, tidak hanya pada satu aspek saja, dalam pembelajaran hasil belajar dapat diperoleh melalui tiga aspek yaitu aspek kognitif, afektif dan psikomotorik. Peneliti memilih bentuk hasil belajar yang digunakan dalam penelitian ini adalah aspek kognitif.

\section{SIMPULAN}

Proses Pelajaran PKn dengan menggunakan model pembelajaran word square di kelas III MIS NU 2 Pontianak dapat diketahui dengan dilakukannya pra-siklus, siklus I dan siklus II untuk mengetahui hasil belajar sebelum diterapkan model word square dan mengetahui hasil belajar siswa setelah diterapkannya model pembelajaran word square yang meliputi langkah-langkah yang sudah dilakukan oleh peneliti dan guru kelas.

Peningkatan hasil belajar siswa dengan model pembelajaran Word Square pada siklus I sebesar 68,5 (kategori baik) dan siswa yang mencapai $K K M \geq 70$ sebesar 55\%. Sedangkan pada siklus II sebesar 82,5 (kategori sangat baik) dan siswa yang mencapai $\mathrm{KKM} \geq 70$ sebesar $90 \%$. Jadi jika di interprestasikan ke tabel distribusi frekuensi maka nilai rata-rata kelas setelah menggunakan model pembelajaran Word Square termasuk pada kategori sangat baik yaitu antara $80-100 \%$.

\footnotetext{
${ }^{13}$ Nana Sudjana, Penelitian Hasil Proses Belajar Mengajar, (Bandung: PT. Remaja Rosdakarya, 2005), 22.

${ }^{14}$ M.Thobroni dan Arif Mustofa, Belajar dan Pembelajaran. Nasional, (Jogjakarta: ArRuz Media, 2013), 22.
} 


\section{DAFTAR PUSTAKA}

Abdullah, Sani Ridwan. Inovasi Pembelajaran. Jakarta: PT. Bumi Aksara, 2013.

Ahmadi, Rulam. Pengantar Pendidikan Asas Dan Filsafat Pendidikan. Yogyakarta: Ar-Ruzz Media, 2016.

Arif, Mustofa. Thobroni Muhammad. Belajar dan Pembelajaran. Nasional. Jogjakarta: Ar-Ruz Media, 2013.

Berlin Sani, Imas Kurniasih. Ragam Pengembangan Model Pembelajaran Untuk Meningkatkan Profesional Guru. Yogyakarta: Kata Pena, 2015.

BSNP. Kurikulum Tingkat Satuan Pendidikan SD/MI. Jakarta: Departemen Pendidikan Nasional. Dalam Fathurrosi. Jurnal Raheema. Volume 4 Nomor 1 2017, 2011.

Fathurrosi Dkk. Pendidikan Pancasila dan Kewarganegaraan. Yogyakarta: Bening Pustaka, 2018.

Haitami Salim \& Erwin Mahrus. Filsafat Pendidikan Islam. Pontianak: STAIN Pontianak Press, 2010.

Jauhar, Hamiyah. Strategi Belajar Mengajar Di Kelas. Jakarta: Prestasi, 2014.

Kementrian Agama RI. Al-Qur`an Dan Terjemahnya. Jakarta: Penerbit Sahifa, 2010.

Kurniasih, Imas. Ragam Pengembangan Model Pembelajaran. Jakarta: Kata Pena, 2015.

Noorhafizah \& Robiah. Jurnal Pradigma. Volume 1-Nomor 1, 2016.

Purwanto dan Thobroni. Belajar dan Pembelajaran. Yogyakarta; Ar-Ruzz Media, 2015. 
Siregar, Syofian. Statistik Deskriptif Untuk Penelitian Dilengkapi Perhitungan Manual Dan Aplikasi SPSS Versi 2017. Jakarta: PT. Raja Grafindo Persada, 2011.

Sugiyono. Metode Penelitian Penilaian Pendidikan Pendekatan Kuantitatif dan Kualitatif dalam R \& D. Bandung: CV. Alfabeta. 2017.

Susanto, Ahmad. Teori Belajar dan Pembelajaran di Sekolah Dasar. Jakarta: Prenadamedia Group, 2013.

Suyadi. Strategi Pembelajaran Pendidikan Karakter. Bandung: Remaja Rosdakarya, 2013.

Undang-undang Republik Indonesia Nomor 20 Tahun 2003. Sistem Pendidikan Nasional. Dalam Fathurrosi Dkk. Pendidikan Pancasila dan Kewarganegaraan. Yogyakarta. Bening Pustaka, 2018.

Yeni, Yuyun Uswatun. Model Word Square Untuk Mrningkatkan Hasil Belajar Siswa Sekolah

Dasar. http://jurnal.ustjogja.ac.id/index.php/snpgsd/article.Diakses/pada/tanggal/28/April/2020. 